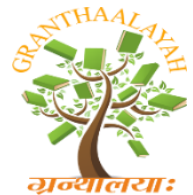

INTERNATIONAL JOURNAL OF RESEARCH GRANTHAALAYAH A knowledge Repository

Management

\title{
A MODEL OF COMMUNITY ECONOMIC EMPOWERMENT BY THE GERAKAN MENULIS HARAPAN (GMH) IN THE CITY OF SURABAYA
}

\author{
Adam Ramadhan Rizzaki ${ }^{1}$, Siti Inayatul Faizah ${ }^{1}$ \\ ${ }^{* 1}$ Islamic Economic Department, Airlangga University, Indonesia
}

\begin{abstract}
Dolly localization is the largest prostitution area in Southeast Asia, located in Putat Jaya, Sawahan District, Surabaya City. On June 182014 the official Dolly localization was closed. After Dolly's closure, the Gerakan Menulis Harapan (GMH) had an extraordinary role of importance to help former commercial sex workers and affected citizens restore the economy in a halal manner with an economic empowerment model. This article aims to analyze the economic empowerment model carried out by GMH on the Community in Putat Jaya Village, Surabaya City. The method used in this article is a qualitative research method with a case study approach. The conclusion of this article is the empowerment of the creative economy through the Guidance program of GMH Surabaya in doing stakeholder synergy with various parties, namely the media, government and donors, as well as the people of Surabaya, especially members of the fostered GMH. To run the GMH coaching program, it receives financial assistance from donors where to carry out economic empowerment through various activities, namely assistance, training and marketing.
\end{abstract}

Keywords: Economic Empowerment; Dolly Localization; Welfare; and Society.

Cite This Article: Adam Ramadhan Rizzaki, and Siti Inayatul Faizah. (2019). "A MODEL OF COMMUNITY ECONOMIC EMPOWERMENT BY THE GERAKAN MENULIS HARAPAN (GMH) IN THE CITY OF SURABAYA." International Journal of Research Granthaalayah, 7(12), 32-38. https://doi.org/10.29121/granthaalayah.v7.i12.2019.298.

\section{Introduction}

Surabaya is the second largest city in Indonesia with the highest number of urbanization after Jakarta, which causes a higher population. Hoping for a better life and work, some people have urbanized urban areas in Surabaya with a total population of 398,143 people coming to Surabaya [1]. But a problem arises with the limited number of jobs that are not in accordance with the abilities and qualities of the self-required to cause high unemployment, one of which is the localization of Dolly.

Dolly localization which is located in Putat Jaya Sub-district, Sawahan Sub-District, Surabaya is one of the bustling areas by migrants or urbanists, totaling 19,792 to find work [1]. Although the localization of dolly economically contributes a lot to the surrounding community and the city 
government of Surabaya, on the one hand there is a morally negative impact. The effort to close Dolly's localization as one of the largest prostitution centers in Southeast Asia requires cooperation and support from various elements of society. Dolly's closure was legally regulated based on the Surabaya Regional Level II Regional Regulation Number 7 of 1999 and East Java Governor Circular Letter Number 460/16474/031/2010 concerning Prevention and Management of Prostitution and Trade. Officially the closure of the localization was carried out on June 18, 2014 by the mayor of Surabaya.

After Dolly's closure, GMH had a very important role to help former commercial sex workers and affected citizens restore the economy in a halal manner. Various aspects such as economics, education, health and women hope to try to be created with a new image that is more positive and changes the negative image of the ex-localization area of Dolly by mapping affected residents into the village of hope, one of which is the affected residents in Pillar IV that are targeted to be used as a gift center [2].

The Gerakan Menulis Harapan (GMH) is one of the Non-Governmental Organization (NGOs) directly involved in designing, printing and rebuilding the more dignified Dolly civilization after the symbolic closure of the localization in the Putat Jaya village. So that this village is no longer the localization area as before. Life and also individuals also go through a process of change into a society that can no longer depend on them and also their lives in the dark business [3].

Muktiana [4] in his research on social communication in the empowerment of former communities. The 'Dolly' localization after the closure resulted in a finding that the Government provided training as a form of program socialization to restore the economic stability of the citizens. Another study conducted by Sukmana and Hapsari [5] (2017) on the Samijali object, which was the first GMH target group established since April 2015. This study aims to describe and analyze the stages in empowering the members of the target.

The difference with previous research is that this research was conducted at a nonprofit institution, namely GMH by paying attention to aspects of community economic empowerment. Herein lies the attractiveness of this research for researchers. Because the big idea is the application of the economic empowerment model that is carried out to empower people in Putat Jaya village, so that people who are members of the fostered community are able to prosper and be independent to realize positive social integration and together rebuild Dolly village.

\section{Method}

This study uses a qualitative approach which is a research method that examines a natural phenomenon in which the writer is a key instrument. Bogdan and Taylor [6], define qualitative methodology as a research procedure that produces descriptive data in the form of written or oral words from people and observable behavior. The qualitative approach aims to obtain a complete picture of a phenomenon according to the human view under study.

According to Moleong [6] a case study is a research method that can use a variety of data sources that are used to research, describe, and comprehensively explain various aspects of research that originate from individuals, groups, institutions, or events systematically. In addition, the case study 
method is more suitable for the main question in a study regarding how or why, a situation where researchers have little opportunity to control the events to be investigated and for research that has a focus on contemporary phenomena (present) in real life.

Based on this explanation, this qualitative research needs to be directed specifically at the use of the case study method. The case study method is considered appropriate for this research because to answer the formulation of this research is how the role of the Hope Painting Movement in its fostered members in the creative economy empowerment. And the topic of this research is the phenomenon of economic empowerment today through community institutions and researchers do not have the opportunity to control what has happened or is happening in the movement to paint hope, and the things that occur in the members of the target. In addition, in this study researchers need data from various sources for the founder, daily chairman, chair of the economy and members of the target to get the data needed.

After collecting data using the above approach, then a data analysis technique is performed. Yin [7] said that the analysis of evidence (data) consists of testing, categorizing, tabulating, or combining evidence to designate the initial proposition of a study. Yin [7] argues about three types of analytical techniques that are often used include pattern matching, making explanations, and time series analysis, so that the analysis technique used in making explanations is to use data analysis methods and describe the results of interview observations, and aims to find out in depth about the usefulness of the hope painting empowerment movement. This data analysis is intended so that data obtained from the field can be easily read and understood as an effort to find answers to research problems. The data analysis process begins with a review of all available data obtained from in-depth interviews and documentation (secondary data utilization). Making an explanation is a narrative form that aims to provide an explanation of the relevant case study that will ultimately be able to prove the propositions made earlier.

\section{Results and Discussions}

Synergy of Stakeholders in Economic Empowerment by GMH in Surabaya City

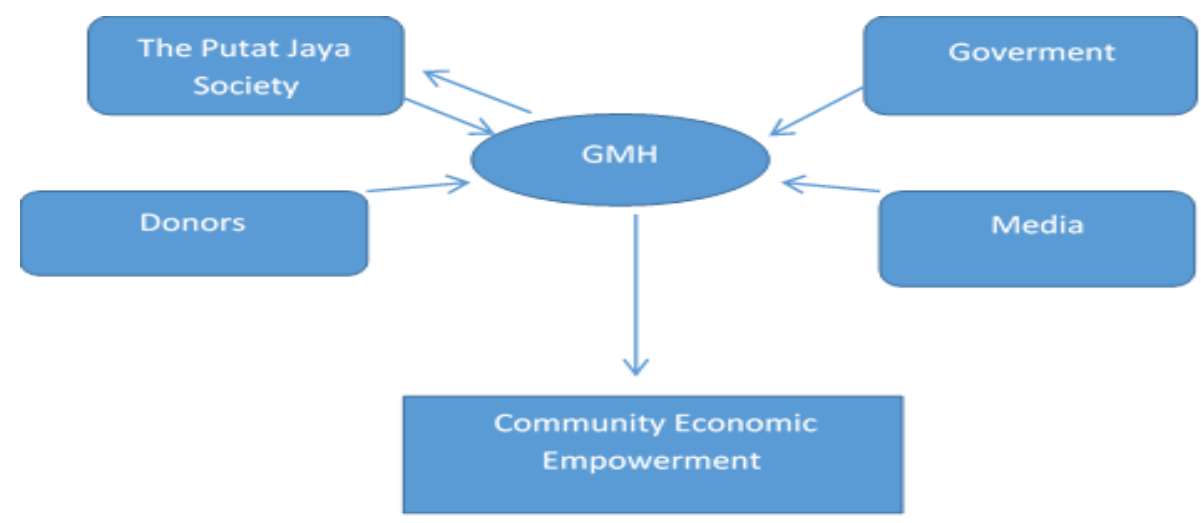

Figure 1: Synergy of Stakeholders

Economic empowerment by GMH requires the synergy of several parties who have their respective roles and functions. The purpose of the synergy of these stakeholders is needed to complement 
each other for the sake of economic empowerment programs, especially for members of the GMH fostered community of Putat Jaya, this is going well.

Economic empowerment involves four stakeholders who have their own roles and functions. Based on Figure 1, there are four stakeholders involved in this program, namely GMH, Society, Media, CSR. The involvement of stakeholders in this economic empowerment are: 1) The first stakeholder is GMH. GMH is the main party in this economic empowerment program for the people of Putat Jaya; 2) The second stakeholder is the Putat Jaya community, a member of the GMH target group which is the most important party in this economic empowerment program because they are the subjects of economic empowerment; 3) The third stakeholder media. The media introduced Dolly and its SMEs to the public as a rebranding effort; 4) the fourth stakeholder is the donor. Donors provide financial assistance to GMH for operational and SME assistance; 5) The role played by GMH is as a facilitator who has aspirations to improve the economy with concepts in this economic empowerment program through training, assistance and planting. It is hoped that this economic empowerment will improve family welfare and overall will improve the economy, especially in the Putat Jaya region; 6) The role of the Putat Jaya community, members of the GMH target, as aspirators who play an important role in running this program because they are the subjects of economic empowerment where every step of the concept formulation, implementation, and evaluation of the program must consider their aspirations so that this program can run well and smooth; 7) Media has a role as a publisher, which is to publish to the public any changes that occur in Dolly, including the Putat Jaya community; 8) donors have the role of funders, namely funders; 9) GMH has an empowerment function that is to run all empowerment programs that have been made in accordance with the plans made; 10) The function of the Putat Jaya community, members of the GMH target group, is as a participatory who makes a real contribution in the economic empowerment program because they are social actors and become a force for the success of this economic empowerment program; 11) The function of the media is informative, where they focus on moving information in the publications that report changes to the better coin; 12) The function of donors as funding is the provision of funds for the smooth operation of empowerment activities as SMEs' operations and assistance; 13) Overall efforts in synergy, roles, and functions of stakeholders are oriented to the success of the economic empowerment program, especially through the community in the Putat Jaya region so that economic improvement, human resource quality and products can be realized and an overall economic improvement for the people can be achieved.

\section{The Community Economic Empowerment Model by the Gerakan Melukis Foundation}

This movement was initiated by a group of youths who supported the policy of the City of Surabaya government to close the distance of Dolly's distance localization on June 18, 2014. Many people realized that the distance-Dolly localization problem was not finished just by closing it. It can actually lead to new, more complex problems if not taken seriously. The youth agreed to intervene to oversee the rehabilitation of the ex localization of Distance Dolly after the closing declaration.

This heavy task will not be completed if only managed by the government. Active community participation is needed to collaborate to form the new face of Distance-Dolly. They are young people called to be part of the improvement of the ex-Dolly ex localization community by forming 
the Gerakan Menulis Harapan Foundation (GMH). On 10 September 2014 the movement was legally recognized as a foundation.

Decades, Putat Jaya Village community wallow in the dark civilization. Since Dolly's localization closure discourse was rolled out, there are groups who agree with the closure of localization and some who refuse. Those who support the closure of localization, argue that the localization violates the religious and ethical laws of the Indonesian people. Another strong reason is that it wants to save the children in this village from the negative impact of the localization environment. There is also a mission to save the woman trapped in the black vortex of Dolly's localization.

In the end, June 182014 symbolically ended the long history of Dolly's localization. With the presence of several parties who are pros and cons to the closure of localization, there are two possibilities that could emerge after the closure of the localization a few months ago. First, the ex localization area is laid out with a new face, far from prostitution activities and the old culture that surrounds it. Second, prostitution activities in the region reopened and old civilizations emerged with more attractive faces. This is where the battle of civilizations in the ex localization of Dolly is happening.

The occurrence of the first or second possibility is very dependent on which party is the most powerful to build a new civilization there. So from here also the first time GMH appeared. GMH wants to be directly involved in designing, printing and rebuilding a more dignified Dolly civilization after the closure with the aim of resolving the problems of affected residents in the Putat Jaya area. This non-profit organization, chaired by Dalu Nuzulul Kirom, emerged as a form of response to the problems that occurred in the community after the closure. GMH has a dream of creating social reforms to realize public welfare, in accordance with the ideals of the Indonesian Nation in opening the 1945 Constitution. In addition, making the ex-localization area of Dolly a tourist village built by its own people with the name Kampung Harapan, which is also one of the ideals GMH ideals. Aside from Kampung Harapan, there are also other programs in the field of community economic empowerment, educational parks, women's development, and health.

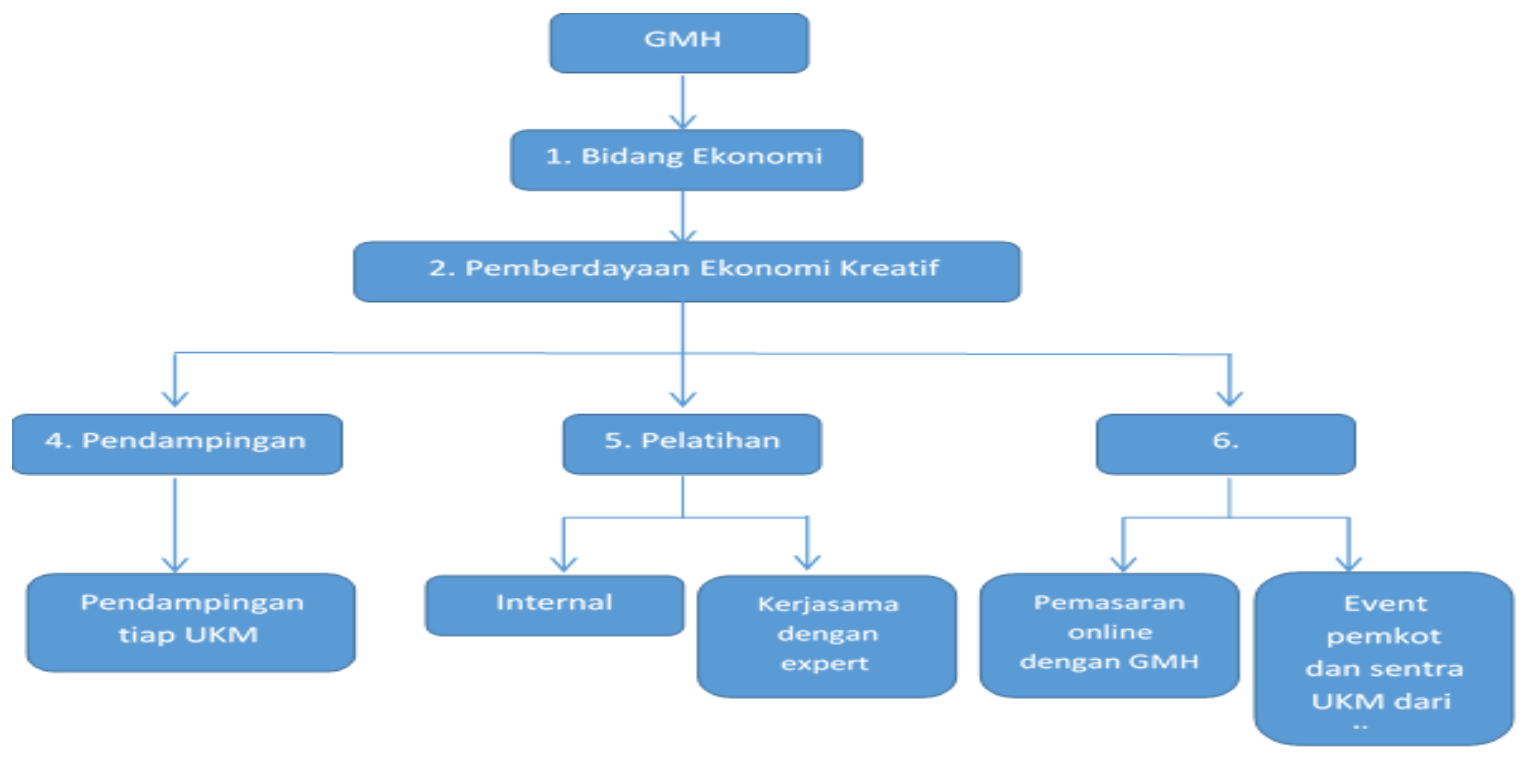

Gambar 2: Model Pemberdayaan Ekonomi oleh Yayasan Gerakan Melukis 
In figure 2 there is a model of economic empowerment carried out by GMH, with the following steps:

- Inside GMH there is a field that deals with efforts to improve the economy, namely the economic field. The aim of the field of Economics is to develop, improve and empower the community's economy, both through entrepreneurship development and skills training;

- With the existence of the field of Economics which is a drafter of this economic empowerment program finally formed patterns of economic empowerment both individual and group SMEs;

- GMH membership began with students conducting searches to verbally encourage empowerment in their place. They approach the community. Joining GMH target members has three benefits, namely in terms of assistance, training, and marketing;

- For assistance, each SMEs will hold regular meetings according to the agreement of each group. From an informal perspective, the companion becomes a story companion for the business group to solve the problem. Approach efforts are needed in carrying out these functions. For now, the facilitator uses a by person approach where this companion needs to establish a more intensive and deep relationship by provoking individual discussion outside the meetings of each group. By doing that, members will usually feel comfortable and finally want to discuss personal problems including business problems they face and the companion can provide input or solutions in solving the problem. A more intimate relationship between members and assistants will create a conducive and harmonious atmosphere that supports cooperative activities. Each routine meeting is not only filled with material from the companion but can be filled with motivation, skills training, and others;

- The second benefit is training. The intended training includes business training. The training was held by internal parties, namely GMH and collaboration with external experts;

- The fourth benefit is in terms of marketing. In marketing there are two channels provided by GMH. The first path is through internal, which is pursued by GMH through online. GMH accompanies SMEs in marketing their products through various. The third path is to take part in local government activities. Within a year the local government usually will hold regional events, both with tourist destinations or indeed to introduce products from SMEs in their area, for example festivals, SMEs product exhibitions, and others. In events such as festivals there will usually be a bazaar which can be filled by the SMEs. So far, GMH has been working with local governments to obtain information about the activities carried out. Usually the local government will contact the SMEs directly concerned to inform the activities that can be filled by the SMEs.

\section{Conclusions}

In carrying out the empowerment of the creative economy through the GMH Development program in the city of Surabaya, the synergy of stakeholders with various parties, namely the media, the government and donors, and the people of Surabaya, especially members of the fostered GMH. To run the GMH coaching program, it receives financial assistance from donors where to carry out economic empowerment through various activities, namely assistance, training and marketing. Meanwhile, suggestions from researchers for GMH are: For GMH, at this final stage it is necessary to look for HR for operations both production, distribution and marketing in each SMEs. Furthermore, it is necessary to discuss further with each SMEs about the sustainability of SMEs in the future to appoint prospective candidates who will continue the SMEs for long-term 
sustainability. Then for further researchers, it is expected to examine the results of GMH development at the further assistance stage because at this stage it is a research that starts from the beginning of the formation (foundation) of SMEs so that they can understand the development and sustainability of SMEs.

\section{References}

[1] Dinas Pendaftaran Penduduk dan Pencatatan Sipil Kota Surabaya, 2014.

[2] Basri, Achmad Chabib Syaiful. 2017. Komunikasi Sosial Yayasan Gerakan Melukis Harapan Dalam Pemberdayaan Masyarakat Di Kelurahan Putat Jaya Surabaya. skripsi. Universitas Islam Negeri Sunan Ampel Surabaya.

[3] Alhifni, A. (2018). Model Pemberdayaan Ekonomi Terpadu Pondok Pesantren Pedesaan Melalui Lembaga Keuangan Mikro Syariah. Surabaya: Perpustakaan Universitas Airlangga.

[4] Muktiana (2014) Komunikasi Sosial Dalam Pemberdayaan Masyarakat Ex. Lokalisasi 'DOLLY' Pasca Penutupan. skripsi.Universitas Islam Negeri Sunan Ampel Surabaya.

[5] Sukmana, Raditya dan Meri Indri Hapsari. 2016. "Model Pemberdayaan Ekonomi Masyarakat Miskin di Lembaga Zakat dalam Kerangka Maqashid Syariah”.Surabaya: Universitas Airlangga.

[6] Moleong, Lexy J. 2014. Metodologi Penelitian Kualitatif: Edisi Revisi. Bandung: PT Remaja Rosdakarya.

[7] Yin, Robert K (2014). Studi Kasus Desain dan Metode, Jakarta: Raja Grafindo Persada

*Corresponding author.

E-mail address: siti-i-f@ feb.unair.ac.id 